DOI: $10.2478 / \mathrm{v} \cdot 10169-011-0016-2$

\title{
COMPUTING INTERNODAL CONDUCTIVITIES IN NUMERICAL MODELING OF TWO DIMENSIONAL UNSATURATED FLOW ON RECTANGULAR GRID
}

\author{
A. SZYMKIEWICZ ${ }^{1}, \mathrm{~K}$. BURZYŃSKI ${ }^{2}$
}

\begin{abstract}
This paper compares numerical solutions of transient two-dimensional unsaturated flow equation by using different averaging schemes for internodal conductivities. Averaging methods such as arithmetic mean, geometric mean, upstream weighting, and integrated mean are taken into account, as well as a recent approach based on steady-state approximation. The latter method proved the most flexible, producing relatively accurate solutions for both downward and upward flow cases.
\end{abstract}

Key words: unsaturated zone, Richards' equation, hydraulic conductivity, finite difference method, finite volume method.

\section{EXTENDED SUMMARY}

Unsteady water flow in partially saturated soil is driven by capillary and gravity forces. It can be described by a parabolic partial differential equation, known as the Richards' equation. Its characteristic feature is a strongly nonlinear relationship between the water potential, saturation and hydraulic conductivity. When the Richards' equation is solved numerically, it is necessary to estimate the average value of the hydraulic conductivity between adjacent nodes, in order to compute the water flux from discrete form of the Darcy's law. The most often used techniques include the arithmetic average, geometric average, upstream weighting, where the value of the conductivity is taken from the node which is positioned upstream with respect to the flow direction, and integrated average, based on the integration of the hydraulic conductivity function for the range of water potentials corresponding to their nodal values. For horizontal flow, the integrated average provides good results, but for vertical flow none of these methods ensures accurate solution for a wide range of boundary conditions, soil parameters and spacing between nodes. Recently, a more accurate approach was proposed, based on the analysis of the steady-state flow between nodes. It consists of three distinct formulas,

\footnotetext{
${ }^{1}$ Gdańsk University of Technology, Faculty of Civil and Environmental Engineering, Department of Geotechnics, Geology and Marine Engineering, ul. Narutowicza 11/12, 80-233 Gdańsk, email: adam.szymkiewicz@wilis.pg.gda.pl

${ }^{2}$ Gdańsk University of Technology, Faculty of Civil and Environmental Engineering, Department of Hydrotechnics, email: kazimierz.burzynski@wilis.pg.gda.pl
} 
one of which is to be chosen, depending on the relation between capillary and gravity forces at the scale of a single grid cell. The performance of various averaging methods was compared for two examples of 2D simulations on rectangular grid, representing downward and upward flow respectively. In the first case, the new averaging method was the most accurate one, while the geometric and integrated averages did not lead to convergent solutions. In the second case, where upward capillary flow was simulated, the geometric mean was the most accurate, the new method being second-best. Thus, it can be concluded that the new method ensures accuracy for both upward and downward flow, in contrast to other existing approaches.

\section{INTRODUCTION}

Water flow in partially saturated soils is commonly described with the Richards' equation (e.g. Zaradny 1990 [14]), which for a two-dimensional isotropic case can be written as follows:

$$
\frac{\partial \theta(h)}{\partial t}-\frac{\partial}{\partial x}\left(K(h) \frac{\partial h}{\partial x}\right)-\frac{\partial}{\partial z}\left(K(h)\left(\frac{\partial h}{\partial z}-1\right)\right)=0
$$

where: $h$-water potential head (negative in the unsaturated zone), $\theta(h)$ - volumetric water content, $K(h)$ - hydraulic conductivity, $t$ - time, $x$ - horizontal coordinate, $z$ - vertical coordinate (oriented positively downwards). Eq. (1.1) represents the law of mass conservation of incompressible fluid with water fluxes expressed by the Darcy's law. The values of $\theta$ and $K$ depend on the water potential in a highly nonlinear manner, which can be described for example by the Brooks-Corey - Mualem model (Zaradny 1990 [14]):

$$
\begin{aligned}
& \theta(h)=\theta_{R}+\left(\theta_{S}-\theta_{R}\right) \cdot\left|h_{E} / h\right|^{\lambda} \quad \text { for } \quad h<h_{E} \\
& K(h)=K_{S} \cdot\left|h_{E} / h\right|^{2+2.5 / \lambda}
\end{aligned}
$$

$$
\begin{aligned}
& \theta(h)=\theta_{S} \\
& K(h)=K_{S}
\end{aligned} \quad \text { for } \quad h \geqslant h_{E}
$$

where: $\theta_{R}$ - residual water content, $\theta_{S}$ - water content at full saturation, $h_{E}$ - air-entry pressure, depending on the size of the largest pores, $\lambda$ - shape parametr, depending on the pore size distribution, $K_{S}-$ hydraulic conductivity at full saturation. The form of Eqs. (1.2-1.3) implies that in unsaturated conditions the values of hydraulic conductivity may differ by several orders of magnitude over relatively small distances. On the other hand, numerical solution of the Richards' equation requires that the average hydraulic conductivity is computed between two adjacent nodes (if the finite difference method is used) or within a single element (if the finite element method is 
used). As it was shown by many authors (e.g. Haverkamp \& Vauclin 1979 [9], Helmig \& Huber 1996 [10], Belfort \& Lehmann 2005 [5]), the choice of averaging method has a significant influence on the solution accuracy. This issue has been considered in detail for finite difference solution of one-dimensional flow (Haverkamp \& Vauclin 1979 [9], Baker 2006 [3], Szymkiewicz 2009 [12]), but the proposed approaches can be easily extended for the case of two-dimensional flow, if Eq. (1.1) is solved with finite difference or finite volume method on a rectangular grid (e.g. Gastó et al. 2002 [8]). In this paper, we examine the accuracy of the averaging scheme proposed by Szymkiewicz (2009) [12] and compare it with other popular averaging methods for the two-dimensional case.

\section{Computing InTERNOdAL CONDUCTIVITIES IN 1D CASE}

Let us consider vertical flow between nodes $U$ (upper) and $L$ (lower), show in Fig. 1a. Replacing the derivative with a differential quotient, one can approximate the water flux between nodes as follows:

$$
q=-K_{A V} \cdot\left(\frac{h_{L}-h_{U}}{z_{L}-z_{U}}-1\right)=-K_{A V} \cdot\left(\frac{\Delta h}{\Delta z}-1\right)
$$

where $K_{A V}$ is the average value of conductivity between nodes $U$ and $L$. The most commonly used averaging methods include:

- arithmetic mean:

$$
K_{A R I T}\left(h_{U}, h_{L}\right)=0.5 \cdot\left(K_{U}+K_{L}\right)
$$

- geometric mean:

$$
K_{G E O M}\left(h_{U}, h_{L}\right)=\sqrt{K_{U} \cdot K_{L}}
$$

- upstream weighting:

$$
K_{U P S}\left(h_{U}, h_{L}\right)=\left\{\begin{array}{ccc}
K_{U}, & \text { if } & \frac{\Delta h}{\Delta z}-1 \leqslant 0 \\
K_{L}, & \text { if } & \frac{\Delta h}{\Delta z}-1>0
\end{array}\right.
$$

- integrated mean: 


$$
K_{I N T}\left(h_{U}, h_{L}\right)=\left\{\begin{array}{ccc}
\frac{1}{\left(h_{L}-h_{U}\right)} \int_{h_{U}}^{h_{L}} K(\psi) d \psi, & \text { gdy } & h_{U} \neq h_{L} \\
K_{U}, & \text { gdy } & h_{U}=h_{L}
\end{array}\right.
$$

On the basis of previously published results (e.g. Forsyth et al. 1995 [7], Miller et al. 1996 [11], Baker et al. 1999 [4], Gastó et al. 2002 [8]) one can conclude that none of these methods is truly universal. Their accuracy depends on the soil type (which determines the form of $K(h)$ function), initial and boundary conditions, and the distance between nodes. In specific conditions each of the methods may lead to large errors in the values of the fluxes or to non-physical oscillations in the water potential within the solution domain.

A more flexible approach seems to be the so-called Darcian mean (from the name of H.Ph. Darcy), proposed by Warrick (1991) [13]. It is based on the assumption that the instantaneous value of the flux between two nodes should be equal to its steady-state value for the considered nodal values of water potential. For horizontal flow the Darcian mean is equal to the integrated mean (Baker 2000 [2]). For vertical flow its value depends on the relation between capillary and gravity forces within a single gridblock, and in most cases can be calculated only approximately (Baker 1995 [1], Baker et al. 1999 [4], Baker 2000 [2], Gasto et al. 2002 [8]). In the paper by Szymkiewicz (2009) [12] the approximating formulas were derived from the analysis of the steady-state pressure profiles between nodes. Three different formulas were proposed, which correspond to various types of flow:

- downward flow with $\Delta h / \Delta z<0$ (infiltration in dry soil):

$$
K_{D A R}=\max \left(K_{I N T}\left(h_{U}, h_{L}\right), \frac{K_{U}}{1-\Delta h / \Delta z}\right)
$$

- downward flow with $1>\Delta h / \Delta z>0$ (drainage, infiltration close to water table):

$$
K_{D A R}=\min \left(\frac{K_{U}}{1-\Delta h / \Delta z}, K\left(h_{L}-\frac{(\Delta h)^{2}}{\Delta z}\right)\right)
$$

- upward flow with $\Delta h / \Delta z>1$ (capillary rise):

$$
K_{D A R}=\frac{\Delta z \cdot K_{A V}^{(1)} \cdot K_{A V}^{(2)}}{(\Delta z-\delta z) \cdot K_{A V}^{(1)}+\delta z \cdot K_{A V}^{(2)}}
$$

where:

$$
\delta z=\frac{-\Delta h+\sqrt{(\Delta h)^{2}+4\left(K_{A V}^{(2)} / K_{A V}^{(1)}-1\right) \cdot(\Delta h-\Delta z) \cdot \Delta z}}{2 \cdot\left(K_{A V}^{(2)} / K_{A V}^{(1)}-1\right)}
$$




$$
K_{A V}^{(1)}=K_{I N T}\left(h_{U}, h_{R}\right), \quad K_{A V}^{(2)}=K\left(h_{R}\right), \quad h_{R}=h_{L}-\Delta z
$$

The proposed approximation of the Darcian mean depends not only on the values of $h_{U}$ i $h_{L}$, but also on $\Delta z$.

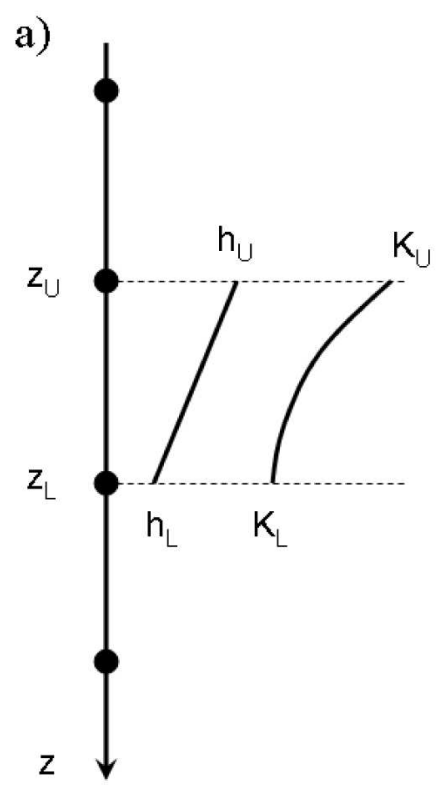

b)

Fig. 1. Spatial discretisation of the unsaturated flow equation: a) one-dimensional in $z$ direction, b) two-dimensional in $x-z$ or $r-z$ plane.

Rys. 1. Dyskretyzacja przestrzenna równania przepływu nienasyconego: a) jednowymiarowego w kierunku $z, \mathrm{~b}$ ) dwuwymiarowego w płaszczyźnie $x-z$ lub $r-z$

\section{NumericAl APPROXIMATION OF 2D PROBLEM ON RECTANGULAR GRID}

Eq. (1.1) is solved on the numerical grid shown in Fig. 1b. The finite volume grid is constructed in such a manner that the cell edges are located mid-way between nodes. Coupling finite volume spatial disctetization with fully implicit time discretization, one obtains the following discrete equation for cell $i, j$ :

$$
\begin{array}{r}
V_{i, j} \frac{\theta\left(h_{i, j}^{k+1}\right)-\theta\left(h_{i, j}^{k}\right)}{\Delta t}+S_{i+1 / 2} \cdot q_{i+1 / 2}-S_{i-1 / 2} \cdot q_{i-1 / 2}+ \\
+S_{j+1 / 2} \cdot q_{j+1 / 2}-S_{j-1 / 2} \cdot q_{j-1 / 2}=0
\end{array}
$$


where: $i$ - spatial index in $x$ direction, $j$ - spatial index in $z$ direction, $k$ - time step index, $V_{i, j}$ - cell volume, $S$ - areas of the outer surfaces of the cell, $q$ - fluxes normal to the outer surfaces of the cell, computed as follows:

$$
\begin{gathered}
q_{i+1 / 2}^{k+1}=-K_{i+1 / 2} \cdot\left(\frac{h_{i+1, j}^{k+1}-h_{i, j}^{k+1}}{\Delta x_{i+1 / 2}}\right), \quad q_{i-1 / 2}^{k+1}=-K_{i-1 / 2} \cdot\left(\frac{h_{i, j}^{k+1}-h_{i-1, j}^{k+1}}{\Delta x_{i-1 / 2}}\right) \\
q_{j+1 / 2}^{k+1}=-K_{j+1 / 2} \cdot\left(\frac{h_{i, j+1}^{k+1}-h_{i, j}^{k+1}}{\Delta z_{j+1 / 2}}-1\right), \quad q_{j-1 / 2}^{k+1}=-K_{j-1 / 2} \cdot\left(\frac{h_{i, j}^{k+1}-h_{i, j-1}^{k+1}}{\Delta z_{j-1 / 2}}-1\right)
\end{gathered}
$$

If the Darcian mean is used, the average conductivities in horizontal direction $K_{i+1 / 2}$ oraz $K_{i-1 / 2}$ are computed as the integrated means from Eq. (4d), while the conductivities in vertical direction $K_{j+1 / 2}$ and $K_{j-1 / 2}$ are computed from Eq. (2.6), (2.7) or (2.8) according to the actual flow conditions. Note that the same approximation can be used for 2D flow in Cartesian coordinates and in cylindrical coordinates - the only differences will be in the volumes and outer areas of the cells.

Substituting formulae (3.2-3.3) into Eq. (3.1), written for each finite volume, a system of nonlinear equations is obtained, whose unknowns represent the values of the water potential at the new time step $h_{i, j}^{k+1}$. This system has to be solved iteratively for each time step. In this case the modified Picard metod (Celia et al. 1990 [6]) is used, which leads to a system of linear equations with sparse matrix in each iteration. The sparse linear system is solved by the conjugated gradient method. A numerical code based on the outlined algorithm was written by the authors and used in the examples presented below.

\section{Numerical EXAMPLES}

\subsection{EXAMPLE 1}

In order to assess the accuracy of the presented averaging approaches for $2 \mathrm{D}$ flow problems, several numerical tests were carried out. Two representative cases are shown in this section.

The first example concerns downward infiltration with prescribed flow rate in sandy soil. Initial and boundary conditions are shown in Fig. 2a. The Brooks-Corey parameters are as follows: $\theta_{R}=0.043, \theta_{S}=0.450, h_{E}=7.1 \mathrm{~cm}, \lambda=0.592$, $K_{S}=5.8 \times 10^{-5} \mathrm{~m} / \mathrm{s}$.

The reference solution was obtained on a dense grid, for which all the conductivity averaging methods provided very similar results. Next, a series of simulations were carried out on coarse grid using various averaging methods described above. The results are compared in Fig. 3. One can see the positions of two isolines of water potential 
a)

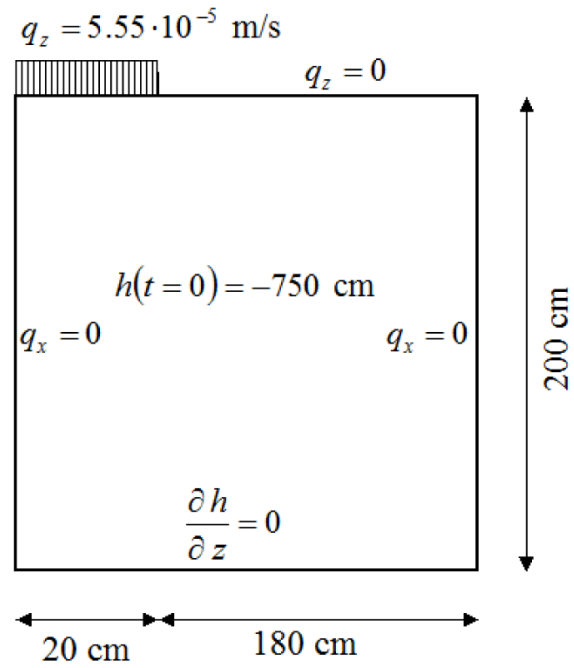

b)

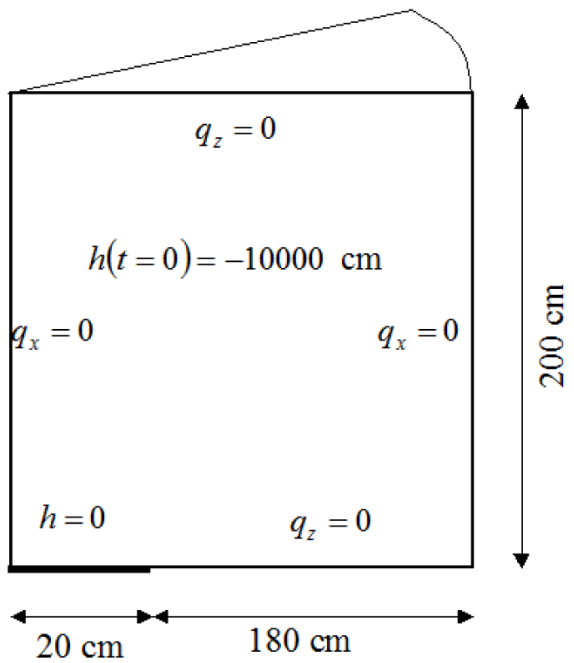

Fig. 2. Solution domain and initial and boundary conditions applied in the numerical examples: a) example 1, b) example 2 .

Rys. 2. Obszar rozwiązania oraz warunki początkowo brzegowe zastosowane w przykładach numerycznych: a) przykład 1, b) przykład 2

head: $-50 \mathrm{~cm}$ i $-700 \mathrm{~cm}$, obtained with different methods. In the reference solution these isolines are close to each other, indicating a sharp infiltration front. This steep shape is virtually impossible to represent on coarse grid - in all other solutions the wetting front is much more diffused. It should be noted however, that the Darcian approach produced the overall shape of the wet zone most similar to the reference solution. The arithmetic and upstream means overestimated significantly the flow rate in horizontal direction, although they were more accurate with respect to the position of the isoline $-700 \mathrm{~cm}$ in the bottom part of the wet zone. It was impossible to obtain convergent solutions using the geometric and integrated mean, which confirmed that they had limited applicability for problems involving infiltration into dry soil. Both methods largely underestimate vertical conductivities, leading to unphysical oscillations in the solution (Baker et al. 1999 [4], Szymkiewicz 2009 [12]). As a quantitative measure of the accuracy of various methods, the root-mean-square error in the potential head can be introduced:

$$
R M S E_{h}=\left(\frac{1}{N} \sum_{i=1}^{N}\left(h_{i}-h_{i, r e f}\right)^{2}\right)^{0.5}
$$

where $h_{i}$ is the value of the potential head at node $i$ for the final time $t=4 \mathrm{~h}$ obtained from the coarse grid solution and $h_{i, r e f}$ is the corresponding value from the reference 
solution. For the Darcian averaging method $\operatorname{RMSE}_{h}=91 \mathrm{~cm}$, for the arithmetic mean $159 \mathrm{~cm}$ and for the upstream mean $176 \mathrm{~cm}$.

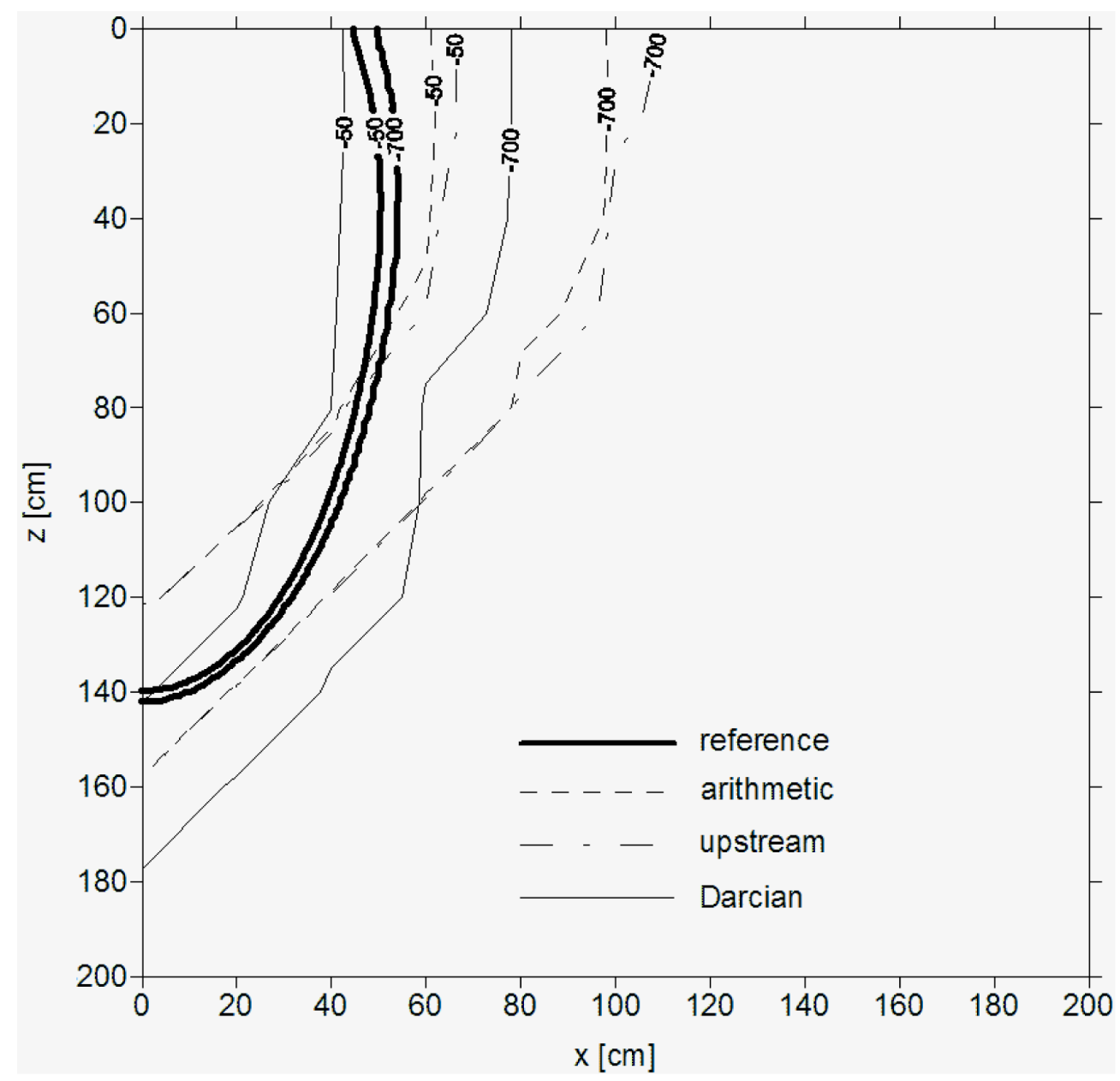

Fig. 3. Example 1: Pressure head isolines after 4 hrs for different conductivity averaging schemes.

Rys. 3. Przykład 1: Izolinie wysokości ciśnienia po 4 godzinach dla różnych sposobów uśredniania przewodności

\subsection{EXAMPLE 2}

In the second case we considered the axi-symmetric upward capillary rise in silty clay (Fig. 2b). The following Brooks-Corey parameters were used: $\theta_{R}=0.056, \theta_{S}=0.423$, $h_{E}=34.5 \mathrm{~cm}, \lambda=0.159, K_{S}=2.5 \times 10^{-7} \mathrm{~m} / \mathrm{s}$. As in the previous, case the reference solution was obtained using a fine grid with $\Delta z=\Delta r=1 \mathrm{~cm}$. In Fig. 4 the reference 


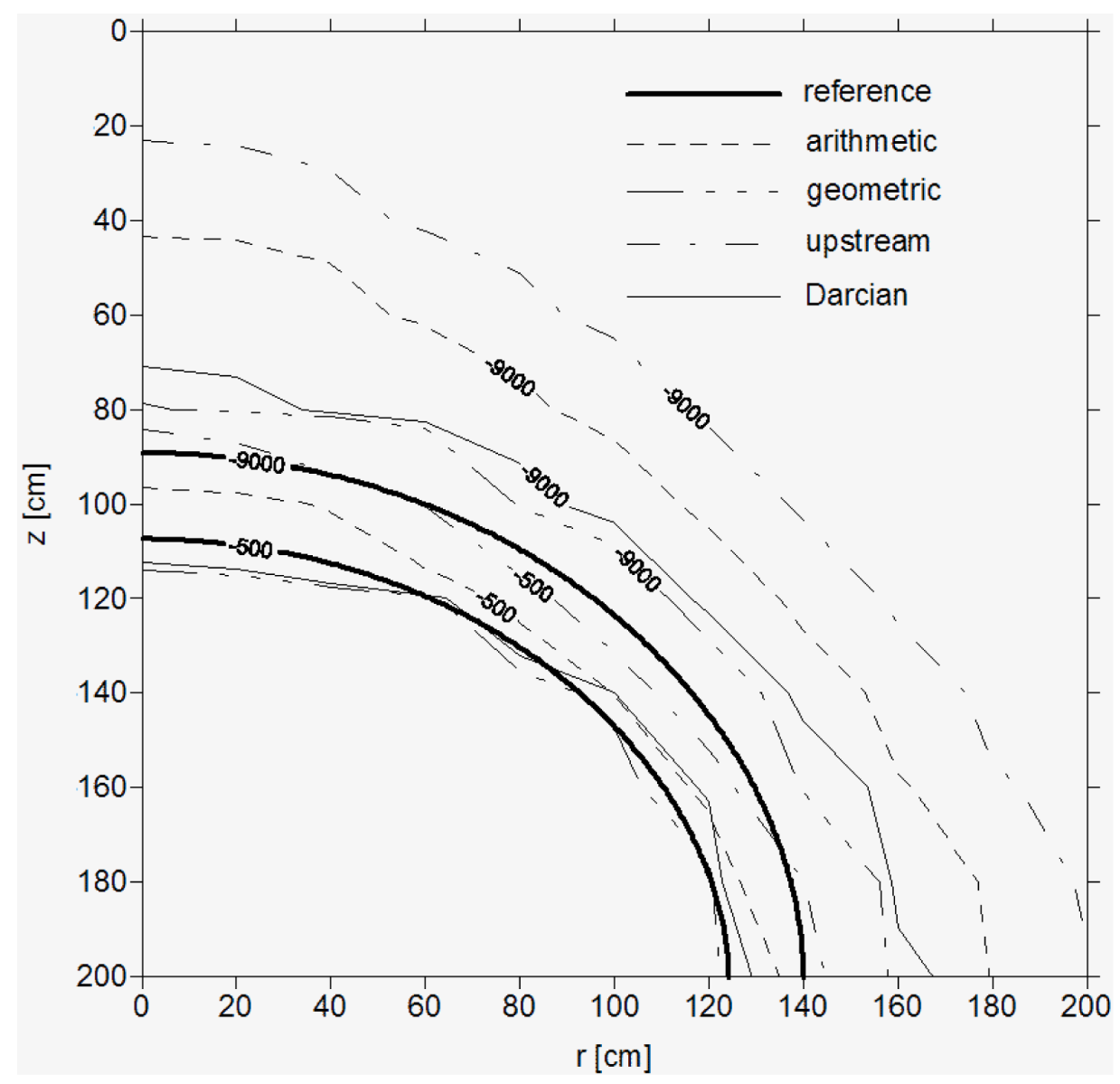

Fig. 4. Example 2: Pressure head isolines after 20 days for different conductivity averaging schemes. Rys. 4. Przykład 2: Izolinie wysokości ciśnienia po 20 dniach dla różnych sposobów uśredniania przewodności

solution is compared to coarse-grid solutions obtained with $x=\Delta z=20 \mathrm{~cm}$ using various averaging methods. The position of water potential isolines $-500 \mathrm{~cm}$ and -9000 $\mathrm{cm}$ after 20 days of upward flow is presented. Again, the results obtained with Darcian mean are in relatively good agreement with the reference solution. Virtually the same results were obtained with the integrated mean, thus they are not shown in the figure. The geometric mean leads to even better results in this case, while the arithmetic and upstream means significantly overestimate the size of the wet zone. In contrast to the previous case, here the total amount of water which enter the domain largely depends on the choice of the averaging scheme. Thus, it is convenient to use the infiltrated volume as an error measure: 


$$
E_{V}=\frac{V-V_{r e f}}{V_{r e f}} \cdot 100 \%
$$

where $V$ is the volume of water that entered the system from the lower boundary according to the coarse grid solution, and $V_{\text {ref }}$ the corresponding value obtained from the reference solution. The errors for various averaging schemes are as follows: geometric $+5.5 \%$, Darcian $+15.3 \%$, integrated $+18.4 \%$, arithmetic $+34.7 \%$ and upstream $+74.6 \%$. This confirms the result of the visual inspection of the isolines, showing that the Darcian averaging method is second best after the geometric mean.

\section{Conclusions}

The presented examples allow us to conclude that the approximate Darcian mean leads to relatively accurate solution on coarse grid for different soils and boundary conditions. Other methods generated significant errors or failed to converge in one of the test cases. In particular, the geometric and integrated mean should be avoided when modeling downward infiltration in dry sandy soils, while they can be used for upward capillary dominated flow. Further research is necessary to evaluate the accuracy and applicability of various methods for unstructured grids.

\section{REFERENCES}

1. D.L. BAKER, Darcian weighted interblock conductivity means for vertical unsaturated flow, Ground Water, 33, 385-390, 1995.

2. D.L. BAKer, A Darcian integral approximation to interblock hydraulic conductivity means in vertical infiltration, Computers and Geosciences, 26, 581-590, 2000.

3. D.L. BAKER, General validity of conductivity means in unsaturated flow, ASCE Journal of Hydrologic Engineering, 11, 526-538, 2006.

4. D.L. BaKer, M.E. Arnold, H.D. Scott, Some analytic and approximate Darcian means, Ground Water, 37, 532-538, 1999.

5. B. Belfort, F. Lehmann, Comparison of equivalent conductivities for numerical simulation of onedimensional unsaturated flow, Vadose Zone Journal, 4, 1191-1200, 2005.

6. M.A. Celia, E.T. Bouloutas, R.L. Zarba, A general mass-conservative numerical solution for the unsaturated flow equation, Water Resources Research, 26, 1483-1496, 1990.

7. P.A. Forsyth, Y.S. Wu, K. Pruess, Robust numerical methods for saturated-unsaturated flow with dry initial conditions in heterogeneous media, Advances in Water Resources, 18, 25-38, 1995.

8. J.M. Gastó, J. Griffol, Y. Cohen, Estimation of internodal permeabilities for numerical simulation of unsaturated flows, Water Resources Research, 38, doi:10.1029/2002WR001529, 2002.

9. R. HAVERKAMP, M. VAucLin, A note on estimating finite difference interblock hydraulic conductivity values for transient unsaturated flow problems, Water Resources Research, 15, 181-187, 1979.

10. R. Helmig, R. Huber, Comparison of Galerkin-type discretization techniques for two-phase flow in heterogeneous porous media, Advances in Water Resources, 21, 697-711, 1996. 
11. C.T. Miller, G.A. Williams, C.T. Kelley, M.D. Tocci, Robust solution of Richards' equation for nonuniform porous media, Water Resources Research, 34, 2599-2610, 1998.

12. A. SzymкIEwicz, Approximation of internodal conductivities in numerical simulation of $1 D$ infiltration, drainage and capillary rise in unsaturated soils, Water Resources Research, 45, doi:10.1029/2008WR007654, 2009.

13. A.W. WARRICK, Numerical approximation of Darcian flow through unsaturated soil, Water Resources Research 27, 1215-1222, 1991.

14. H. ZARADNY, Mathematical methods for description and solutions of water flow problems in saturated and unsaturated grounds and soils. [In Polish], Prace Instytutu Budownictwa Wodnego PAN, nr 23, 1990.

Streszczenie

W artykule porównano rozwiązania numeryczne dwuwymiarowego równania przepływu nienasyconego z użyciem różnych metod uśredniania współczynnika przewodności hydraulicznej między sąsiednimi węzłami. Uwzględniono średnią arytmetyczną, geometryczną, "pod prąd" oraz całkową, a także niedawno zaproponowany sposób uśredniania oparty na analizie przepływu ustalonego. Ten ostatni sposób okazał się najbardziej uniwersalny, gdyż umożliwiał otrzymanie stosunkowo dokładnych wyników dla przepływu wody w strefie nienasyconej zarówno w kierunku w dół jak i w górę.

Remarks on the paper should be sent to the Editorial Office

no later than September 30, 2011
Received December 15, 2010 revised version June 7, 2011 